\title{
Reading Aids in Early Christian Papyri
}

\section{Introduction}

This contribution offers a discussion of the issues related to the function of reading aids in early Christian papyri, in view of the role assigned to these elements in recent scholarship. To that end, it will briefly introduce the question in the context of early Christian studies, discuss in some detail a recent proposal with regard to reading aids in canonical gospels papyri, and present some further data from apocryphal and apostolic fathers papyri, before offering a number of considerations in conclusion.

The background for this is the fact that "the scholarly interest in early Christian (and in particular New Testament) manuscripts as artifacts has witnessed a remarkable growth in the last couple of decades alongside a parallel increase in the attention paid to materiality and material practices in the study of religious phenomena more broadly conceived." In this context, various paratextual features such as the distribution and execution of titles and subtitles, the use of paragraphing and punctuation, the existence of corrections and glosses, as well as potential lectional signs are often taken as possible indicators of how early Christians treated and used their texts. ${ }^{2}$ Alternatively, such factors are taken as clues for tracing the history of the transmission and reception of early Christian texts copied in the papyri. ${ }^{3}$ Indeed, the fact that we have Christian manuscripts

1 Giovanni Bazzana, “'Write in a Book What You See and Send It to the Seven Assemblies:' Ancient Reading Practices and the Earliest Papyri of Revelation," in Book of Seven Seals: The Peculiarity of Revelation, its Manuscripts, Attestation, and Transmission, ed. Thomas J. Kraus and Michael Sommer, WUNT 363 (Tübingen: Mohr Siebeck, 2016): 11-31, at 11.

2 See, for instance, Larry W. Hurtado, The Earliest Christian Artifacts: Manuscripts and Christian Origins (Grand Rapids, MI: Eerdmans, 2006), 34-41 and 81-83; Larry Hurtado, “The Greek Fragments of the Gospel of Thomas as Artefacts: Papyrological Observations on Papyrus Oxyrhynchus 1, Papyrus Oxyrhynchus 654 and Papyrus Oxyrhynchus 655," in Das Thomasevangelium: Entstehung - Rezeption - Theologie, ed. J. Frey, E.E. Popkes and Jens Schröter, BZNW 157 (Berlin: de Gruyter, 2008): 19-32; AnneMarie Luijendijk, "Reading the Gospel of Thomas in the Third Century: Three Oxyrhynchus Papyri and Origen's Homilies," in Reading New Testament Papyri in Context/Lire les papyrus du Nouveau Testament dans leur contexte, ed. C. Clivaz and J. Zumstein, BETL 242 (Leuven: Peeters, 2011): 241-67.

3 A recent example is available in Peter Malik, "The Greek Text of Revelation in Late Antique Egypt: Materials, Texts, and Social History," ZAC 22 (2018): 400-21. See also Dan Batovici, “The Apostolic Fathers in Codex Sinaiticus and Alexandrinus," Biblica 97 (2016): 581-605, or Bazzana, “Ancient Reading Practices," 11-31, and Juan Chapa, "Su demoni e angeli: Il Salmo 90 nel suo

D Open Access. (C) 2020 Dan Batovici, published by De Gruyter. (๕) BY-NC-ND This work is licensed under a Creative Commons Attribution-NonCommercial-NoDerivatives 4.0 International License.

https://doi.org/10.1515/9783110634440-003 
from the second and third centuries means that we have in them artefacts which were copied and used by actual Christians, and as such bear the promise of a glimpse into the life and habits of early Christians, a notion which, unsurprisingly, has attracted significant attention in recent years from scholars of early Christianity.

Of course, early and late-antique Christianity is not the only manuscript culture where research has been done on the ways in which texts are organized and adapted for reading. In Arabic manuscript studies there is also a growing interest in studying the witnesses as artefacts and not only for the texts they carry. For instance, Adam Gacek's Vademecum for Readers includes entries on abbreviations and abbreviations symbols, book titles, calligraphy and penmanship, chapter and section headings, conjunction marks, glosses and scholia, marginalia, textual dividers and paragraph marks, ${ }^{4}$ as well as other paratextual features in early Qur'ānic texts which point to what is a very developed and complex phenomenology of reading and copying (for more on this, see the chapter from Fedeli in the present volume). There is also a growing literature on scribal practices in Hebrew manuscript culture, especially on the Dead Sea Scrolls fragments. The seminal work of Emanuel Tov, for instance, includes chapters on writing practices, sections on titles of compositions and headers of sections, word and small sense unit division, scribal marks and procedures, as well as appendices on characteristic features of the Qumran scribal practices, and on scribal features of biblical manuscripts, ${ }^{5}$ reflecting a multifaceted, reader-oriented, manuscript culture (see the chapter from Krauß and SchückingJungblut in this volume).

While such connections are interesting and illuminating, the background for early Christian Greek papyri, however, is formed for the most part in relation to the larger Greek papyrus culture, and especially the papyri of classical literature. The few pages devoted to the topic in E.G. Turner's introduction to his important Greek Manuscripts of the Ancient World, first published in 1971 then revised by P.J. Parsons a decade later, are perhaps the most cited when the classical background

contesto," in I papiri letterari Cristiani: atti del Convegno internazionale di studi in memoria di Mario Naldini. Firenze, 10-11 giugno 2010, ed. Guido Bastianini and Angelo Casanova, Studi e Testi di Papirologia N.S. 13 (Firenze: Instituto Papirologico “G. Vitelli,” 2011): 59-90.

4 Adam Gacek, Arabic Manuscripts: A Vademecum for Readers, HOSNME 98 (Leiden: Brill, 2009), respectively at 2-6, 37-38, 43-47, 57-58, 81, 114-17, 156, 268-270.

5 Emanuel Tov, Scribal Practices and Approaches Reflected in the Texts Found in the Judean Desert, STDJ 54 (Leiden: Brill, 2004). For a more focused approach, see Stephen Reed, "Physical Features of Excerpted Torah Texts," in Jewish and Christian Scripture as Artifact and Canon, ed. Craig A. Evans and H. Daniel Zacharias, LSTS 60 (London: Bloomsbury, 2009): 82-104. 
of Christian Greek papyri is mentioned. ${ }^{6}$ Therein several paratextual features are introduced and discussed, and these still inform the current treatments of early Christian papyri. After a brief mention of the relevance of the width of the column of copied text, the various ways in which a text in scriptio continua can be segmented are discussed one after another: the rare practice of forming word groups, oblique strokes as (again, rather rare) markers of phrases or individual words, abbreviations, apostrophe, punctuation as a later invention, rarely used and in the absence of a standardized system beyond working as separators, ekthesis (the projection of a first word or letter in the left margin), eisthesis (an indentation, in fact the opposite of an ekthesis), blank spaces to separate sentences, paragraphi as horizontal strokes below the line which is so marked, the double dot, high dot, and middle dot, diairesis, breathings and accents, coronis (by which he means a paragraphus with further lines at one end as, for instance, the so-called forked paragraphus $>-$ ), titles and subtitles, the diple (>), nomina sacra, and various ways to perform corrections. ${ }^{7}$ Turner's description still provides the current working terminology and typology for research on early Christian papyri from this perspective.

More recently, an important collective volume was published with the aim of updating our knowledge on paratextual signs in the Greco-Roman world by way of a comparative approach from papyri to inscriptions, and from Greek to Latin. ${ }^{8}$ It offers sixteen contributions on the Greek and Roman background of signs found in manuscripts and inscriptions and should therefore inform future developments on early Christian papyri. Kathleen McNamee's chapter on "Sigla in Late Greek Literary Papyri" is particularly interesting in that it offers a wide-ranging discussion of paratextual signs in late-antique Classical literary papyri, ${ }^{9}$ from old signs with old uses, to and old signs with new uses, to altogether new sigla. Among the inherited paratextual features which keep their older use, McNamee discusses the diple ( $>$ ) which, while normally placed at the beginning of the line, still signals quotations, the diagonal slash (/), which is still used inconsistently for various reasons, such as marking errors or the beginning of a new section or passages which are interesting in some way, and

6 E. G. Turner, "Introduction," in Greek Manuscripts of the Ancient World, second edition revised and enlarged, ed. P.J. Parsons (London: Institute of Classical Studies, 1987): 1-23.

7 Turner, "Introduction," 7-17.

8 Gabriel Nocchi Macedo and Maria Chiara Scappaticcio, eds., Signes dans les textes, textes sur les signes: Érudition, lecture et écriture dans le monde gréco-romain, Papyrologica Leodiensia 6 (Liège: Presses Universitaires de Liège, 2017).

9 Kathleen McNamee, “Sigla in Late Greek Literary Papyri," in Nocchi Macedo and Scappaticcio, Signes dans les textes, textes sur les signes, 127-41. 
the dot (stigme), which is placed, in her examples, in the margin to indicate "a textual peculiarity in a line" or between a lemma and its comment. ${ }^{10}$ Among the old sigla which were put to new use in late antiquity, McNamee includes the paragraphus and the diple obelismene (>- , described by Turner as a forked paragraphus, and as a particular type of coronis), which "continues to be written in the left margin, between lines, to indicate a new section of text," but which is now also used to separate "material within the line."11 The author concludes with a description of new and newly proliferating sigla. For instance, the older, more austere, signs employed to "articulate parts of a text," such as "the horizontal paragraphus, diple obelismene, and (at the conclusion of a piece) a cornis of fairly standard shape," make way in late antiquity for more developed forms of coronis and more elaborate as well as variate paragraphi, as can be found, for instance, in Codex Sinaiticus. ${ }^{12}$ She also notes the use of larger diplae (>) with the function of a paragraphus in as much as "they do not mark individual lines but are written, instead, between lines or after sections of text."13 All in all, McNamee draws attention to the lack of similar studies on the Christian Latin, Greek and Coptic manuscripts. ${ }^{14}$

\section{Reading Early Christian Papyri in Early Christian Studies}

A peculiarity of the assessment of reading aids in Christian papyri is the fact that they have been set in relation to ongoing debates concerning the history and development of early and late-antique Christianity, notably with regard to the development of the New Testament canon.

In relatively recent scholarship we can find, for instance, the argument that the three Greek papyri of the Gospel of Thomas - P.Oxy. 1, 654, and 655 - do not "reflect a regard for this text as "scripture" to be read in worship and treated

10 McNamee, "Sigla in Late Greek Literary Papyri," 128-30, quotes from 130.

11 McNamee, "Sigla in Late Greek Literary Papyri," 131, emphasis added. What follows is also interesting, because in samples the variety of contexts in which it is used: "Among later classical texts, > - separates medical prescriptions, sections of a medical catechism, Hippocratic aphorisms, passages of dense marginalia, and perhaps parts of a commentary on Aristophanes Pax (unless here it is a space filler at the end of the line)."

12 McNamee, "Sigla in Late Greek Literary Papyri," 131.

13 McNamee, "Sigla in Late Greek Literary Papyri," 132.

14 McNamee, "Sigla in Late Greek Literary Papyri," 128. 
somehow authoritative for faith."15 The argument is based on the format, appearance and the comparative quality, or lack thereof, of these manuscripts. This would depend, of course, on the level of uniformity that we presuppose existed with early Christianity. It is not clear how one could rule out either - especially the latter. The conclusion of this particular argument is that the three papyri offer "strong reasons" to doubt that those who used them considered them "scriptural". One wonders whether there is any reason at all, let alone strong ones to reach such a conclusion. Is it impossible that those Christians considered the text "scriptural" but also used a "private" papyrus of it (however one chooses to define "private")? To take a more extreme case, it is hard to imagine why an amulet, or a writing exercise, or a miniature papyrus with verses from the Gospel of John would indicate that those who used them as such did not consider it “canonical”.

Indeed, taking a different approach with regard to the same P.Oxy. 654 of the Gospel of Thomas, AnneMarie Luijendijk has noted, for instance, that, "inscribed with reader's aids, the Thomas roll appears intended for reciting," suggesting further that it "might have been used in a liturgical setting," or it "may have been intended for reading out loud in a different context, for instance in an educational setting," or else "the scribe might have copied the punctuation from the Vorlage," which would also point to an exemplar "intended for declamation."16 Therefore, there are scholarly takes which try to situate such papyri not only with respect to their probable use in early Christianity, but also in relation to the history of the formation of the New Testament canon.

In a recent contribution, Dan Nässelqvist too offers a discussion of how paratextual features of early Christian papyri might have influenced public reading of papyri. ${ }^{17}$ However, his argument is that, when "pragmatics of reading" are considered, "abbreviations and lectional signs [in early New Testament papyri] were employed infrequently, unsystematically, and at times in ways that render public reading more difficult." 18 In claiming this, he is challenging the notion that early Christian paratextual features were "lectional signs" meant to aid public reading,

15 Hurtado, Early Christian Artifacts, 34, reacting specifically to the title of Bentley Layton, The Gnostic Scriptures: A New Translation with Annotations and Introductions (New York: Doubleday, 1987).

16 Luijendijk, "Reading the Gospel of Thomas in the Third Century," 253-54.

17 Dan Nässelqvist, Public Reading in Early Christianity: Lectors, Manuscripts, and Sound in the Oral Delivery of John 1-4, NovTSup 163 (Leiden: Brill, 2016), 17-62.

18 Nässelqvist, Public Reading in Early Christianity, 322. 
while also suggesting that they are perhaps more likely to have worked as "reader's aids" for the private reader. ${ }^{19}$

As such, the interest raised by paratextual features in early Christian papyri taken as possible reading aids has brought about a scholarly discussion concerning a posited distinction between public and private use of these papyri. Generally speaking, whether a manuscript is or is not meant for private use is a fairly common sort of estimation in most areas of manuscript studies, where it is normally taken in a neutral manner. However, this becomes quite a sharp distinction precisely when the underlining presupposition is that public reading in early Christian churches might indicate canonical status.

\section{Public and Private: Charlesworth's Early Christian Gospels}

The most developed attempt so far to situate paratextual features as reading aids is arguably that by Scott Charlesworth in his 2016 book on the production and transmission of Early Christian Gospels, which aims to compare the papyri of the canonical and non-canonical gospels. ${ }^{20}$ The author proceeds by picking a literary genre, that is the gospel genre, and then draws a comparison across the clear-cut categories of canonical and non-canonical, largely on two levels: from the point of view of codicology and palaeography on the one hand, and from the perspective of textual stability on the other.

In the following, Charlesworth's codicological and palaeographical discussion is particularly of interest, as it addresses in the process the related issue of establishing whether a papyrus is meant for private or public use. This matter is covered in the second chapter of his book - entitled "Public and Private: Early Christian Codicological Conventions" - which is an attempt to describe and systematise reading aids in papyri of the four canonical gospels. ${ }^{21}$ In view of this, the starting point is the assumption that "early canonical gospel MSS were used in two general settings - publicly in corporate worship, and privately by indi-

19 Nässelqvist, Public Reading in Early Christianity, 323.

20 Scott D. Charlesworth, Early Christian Gospels: Their Production and Transmission, Papyrologica Florentina 47 (Firenze: Edizioni Gonnelli, 2016).

21 Charlesworth, Early Christian Gospels, 31-92, which is a developed version of Scott D. Charlesworth, "Public and Private: Second- and Third-Century Gospel Manuscripts," in Jewish and Christian Scripture as Artifact and Canon, ed. Craig A. Evans and H. Daniel Zacharias, LSTS 70 (London: Bloomsbury, 2009): 148-75. 
viduals." The general argument is that "the majority of second-century canonical gospel manuscripts (MSS) can be designated 'public,' in the sense that they were intentionally produced to be read aloud by lectors in Christian meetings."22

Commendably, the author is cautious when mentioning that "it is important to recognize that the categories of 'public/controlled' and 'private/uncontrolled' should not be seen as inflexible classifications to be imposed on the evidence."23 At the same time, he maintains that "nonetheless, the manuscript evidence clearly supports the notion that early canonical gospel MSS were used and produced in broad 'public/controlled' and 'private/uncontrolled' settings."24

Charlesworth then proposes four categories of early papyri of the canonical gospels, based on the size and format of codices, script (whether copied by a bookhand, or a more informal hand, or documentary) and - of relevance for the present contribution - "types of text division and/or punctuation": the presence (or lack thereof) of paragraphi, vacant line ends, ekthesis, enlarged first letter, space, medial or high point, dicolon, apostrophe, diple as line filler and "acutelike text division marker or miscellaneous stroke." ${ }^{25}$ The fourfold categorisation is therefore based on paratextual features and goes as follows: (a) controlled production of "public" canonical gospels, (b) probable and possible "public/controlled" manuscripts, (c) uncontrolled production of "private" canonical gospels, and (d) probable and possible "private/uncontrolled" manuscripts. ${ }^{26}$ As it were, Charlesworth proposes two main categories - public and controlled manuscripts, opposed to private and uncontrolled - and two additional ones with manuscripts which are close to either of the main two, but not enough to make it in. With these categories as framework, the general characterisation of non-canonical gospels papyri is then that they are, as the title of the corresponding chapter puts it, "private and marginal."27

The analysis of the data is thorough and interesting, and its main result is that it puts in the spotlight the differences in terms of size, scribal hand, and paratextual features among New Testament gospel papyri up to the fourth century. Yet the reconstruction proposed on the basis of the analysis invites some scrutiny. For instance, Charlesworth's proposal, which was initially formulated in the terms that "most [major manuscripts] were copied in controlled settings where

22 Charlesworth, Early Christian Gospels, 31.

23 Charlesworth, Early Christian Gospels, 31.

24 Charlesworth, Early Christian Gospels, 31.

25 Charlesworth, Early Christian Gospels, 35-36.

26 Charlesworth, Early Christian Gospels, 40. The full description of the four categories then follows on pages 42-84.

27 Charlesworth, Early Christian Gospels, 121. 
policy dictated some aspects of production,"28 has already met some criticism from scholars for whom this notion is "without basis and stands at odds with papyrological evidence," 29 mostly because "unfortunately, we have hardly any information about the production sites of Christian texts in this period." 30

Indeed, the proposed way of categorising canonical gospel papyri invites a number of considerations. In particular, one wonders whether setting these categories - controlled and public, uncontrolled and private, and the two grey areas for each - is really more than just to say that there are differences from one manuscript to another, and that they can be grouped according to these differences: papyri with many reading aids, others with a smaller number of such features, others still with scarcely any paratextual features. Beyond that, claiming that they are "public/controlled" or "private/uncontrolled" comes in the form of an undemonstrated assumption.

To illustrate, in the introduction of the chapter the author indicates programmatically that "paucity or irregularity of text division, punctuation and lectional aids will be taken to be an indication that a MS was produced for private rather than public use, especially when coupled with a documentary hand," and then announces that the "analysis of the 3rd century evidence will show that the lack of such features can often be traced to an uncontrolled production stetting." 31 Indeed, it would be great to be able to trace down any production setting for early Christian papyri. However, the book does not offer external evidence to corroborate the proposal, as both the uncontrolled and the controlled production setting are presupposed. Instead, what we get as conclusion at the end of the analysis of one particular manuscript is, for instance, that "the cursive tendency of the hand, the use of a roll, and absence of text division, denote uncontrolled/private production for private use." 32

It is important, then, to stress the point that whether (or not) these features are indicators of private rather than public use is precisely the question, and therefore it cannot also be the answer. Charlesworth may well be right that that particular manuscript was meant for private use, but this is not proven in his book. It is simply presupposed from the outset. The author documents - in great,

28 Scott D. Charlesworth, "Consensus Standardization in the Systematic Approach to Nomina Sacra in Second- and Third-Century Gospel Manuscripts," Aegyptus 86 (2006): 37-68, at 66.

29 Kim Haines-Eitzen, "Social History of Early Christian Scribes," in The Text of the New Testament in Contemporary Research: Essays on the Status Quaestionis, ed. Bart D. Ehrman and Michael W. Holmes, NTTSD 42 (Leiden: Brill, 2013): 479-95, at 491.

30 Luijendijk, "Reading the Gospel of Thomas in the Third Century," 255, n. 58.

31 Charlesworth, Early Christian Gospels, 34-35.

32 Charlesworth, Early Christian Gospels, 75. 
and often interesting, detail - just how well a manuscript is adorned with reading aids compared to other manuscripts which have barely any reading aids, and are poorly written. Perhaps most of all this emphasizes once again the fragmentary and scarce nature of the available evidence, and the limitations that come with the reconstructions we attempt. We have some manuscripts which are larger, more competently copied, and with more paratextual features than others, and we indeed can and should categorize those accordingly. But the reconstructions we can attempt starting from "reading aids" seem to remain riddled with limitations and blind spots.

Similarly, with regard to the comparison between canonical and noncanonical gospels papyri, Charlesworth's description of the latter as "private and marginal," 33 rather than telling us something about their use as artefacts read by early Christians, tells us simply what we already know: there are far more and better copied papyri of the canonical gospels. But it does so in a detailed manner and from a fresh perspective, and future studies will certainly profit from it.

\section{Reading Other Early Christian Papyri}

Judging from the surviving papyri, early Christians read and copied texts other than the canonical gospels as well. ${ }^{34}$ Indeed, as mentioned, Charlesworth includes in his treatment not only canonical, but also non-canonical gospels, and it is of course generally suitable for the purpose of a comparison to select papyri of the same genre across the canonical border. However, the definition of the gospel genre (apart from the four canonical ones) is notoriously problematic. ${ }^{35}$ Moreover, for several non-canonical gospel papyri, as Charlesworth recognizes, ${ }^{36}$ it is

33 Charlesworth, Early Christian Gospels, 121.

34 Most recently, see Lincoln H. Blumell and Thomas A. Wayment, Christian Oxyrhynchus: Texts, Documents, and Sources (Baylor: Baylor University Press, 2018). Other important contributions are Lincoln H. Blumell, Lettered Christians: Christians, Letters, and Late Antique Oxyrhynchus, NTTSD 39 (Leiden: Brill, 2012); AnneMarie Luijendijk, Greetings in the Lord: Early Christians and the Oxyrhynchus Papyri, HTS 60 (Cambridge, MS: Harvard University Press, 2008); Kim Haines-Eitzen, Guardians of Letters: Literacy, Power and the Transmitters of Early Christian Literature (Oxford: Oxford University Press, 2000).

35 See, for instance, the discussion in Lorne R. Zelyck, "Identifying the Extra-Canonical Gospels," in his John among the Other Gospels, WUNT 2/347 (Tübingen: Mohr Siebeck, 2013), 3-12. The same goes for the category of apocrypha in general. See Christopher Tuckett, "What is Early Christian Apocrypha?", in The Oxford Handbook of Early Christian Apocrypha, ed. Andrew Gregory and Christopher Tuckett (Oxford: Oxford University Press, 2015): 3-12.

36 E.g. Charlesworth, Early Christian Gospels, 135. 
not clear at all whether they contain gospel texts proper, or gospel-like texts, or fragments of exegetic or homiletic works, or exercises of some kind, to the effect that the non-canonical gospels sample may be too small to serve this purpose. Outside this sample, however there are papyri with known apocryphal works of other genres which are better represented, for instance the Apocryphal Acts, or the Protoevangelium of James. ${ }^{37}$ There are also papyri of other texts for which there are claims that they might have been at some point candidates for canonical status, such as the Didache and the Shepherd of Hermas, some of which also survived in comparatively bigger numbers.

Based on my research exploring a sample of forty-nine continuous Greek literary papyri of apocrypha and apostolic fathers, ${ }^{38}$ the study of paratextual features yields a host of possible reading aids ranging from diaeresis, breathings and accents, apostrophes, to ekthesis (protruding the beginning of a sentence in the margin), enlarged letters, paragraphus, diple, dots, blank spaces, and oblique lines above the text. Much like in other papyri, more often than not these are employed inconsistently throughout this sample of papyri, acting more like sense separators in an otherwise continuous text - differing in this respect, for example, from the consistently deployed, sense-unit delimiting function of modern punctuation.

However, it is important to outline the fact that not all paratextual features function in the same way with regard to the manner in which they might aid reading. The diaeresis over initial $\mathrm{\iota}$ and $v$ is a fairly common paratextual feature, just as in other papyri, among the apocryphal and apostolic fathers papyri and can be found in P.Egerton 2 + P.Köln VI 255, P. Oxy. LXXVI 5072, P.Oxy. II 210, P.Oxy. X 1224, P.Oxy. I 1, P.Oxy. IV 654, P.Oxy. LXIX 4706, P.Mich. II 2.129, P.Mich. II 2.130, P. Oxy. LXIX 4707, P.Bodmer 38, BKT VI 2.2, P.Mich. 1317 + P.Mich. 3788 + P.Berol 13893, P.Hamburger 1, P.Bodmer 10, P.Oxy. L 3525, P.Ryl. III 463, Bodl. Ms Gr. tb. f. 4 [P] + P.Vindob.G 39756, Greek Papyrus JE 85643, PSI I 6, P.Bodmer 5 and P.Grenf. I 8. Just like breathings and accents - found, for instance, in P.Oxy. V 840, P.Ryl. III 463, and P.Mich. II 2.130 - diareses can hardly be construed as lectional

37 A useful reference tool is now Thomas A. Wayment, The Text of the New Testament Apocrypha (100-400) (New York: Bloomsbury, 2013).

38 Bodl. Ms Gr. tb. f. 4 [P] + P.Vindob.G 39756, BKT VI 2.2, Greek Papyrus JE 85643, P.Antinoopolis I 13, P.Ashmolean inv. 9, P.Berol 13272, P.Bodmer 5, P.Bodmer 10, P.Bodmer 38, P.Egerton $2+$ P.Köln VI 255, P.Grenf. I 8, P.Hamburger 1, P.Hamburg inv. 24, P.Harris I 128, P.Oxy. I 1, P.Oxy. II 210, P.Oxy. III 404, P.Oxy. IV 654, P.Oxy. IV 655, P.Oxy. V 840, P.Oxy. VI 849, P.Oxy. VI 850, P.Oxy. VIII 1081, P.Oxy. X 1224, P.Oxy. XIII 1599, P.Oxy XIII 1602, P.Oxy. XV 1782, P.Oxy. XV 1783, P.Oxy. XV 1828, P.Oxy. L 3524, P.Oxy. L 3525, P.Oxy. L 3526 + P.Oxy. IX 1172, P.Oxy. L 3527, P. Oxy. LX 4009, P. Oxy. LXIX 4705, P.Oxy. LXIX 4706, P.Oxy. LXIX 4707, P.Oxy. LXXVI 5072, P.Merton II 51, P.Mich. II 2.129, P.Mich. II 2.130, P.Mich. 1317 + P.Mich. 3788 + P.Berol 13893, P.Prag. I 1 + P. Weill I 96, P.Ryl. III 463, P.Schøyen I 21, PSI I 6, PSI VII 757, P.Vindob.G 2325, and P.Vindob.G 39756 [49]. 
aids. Dan Nässelqvist, for instance, describes these as "lectional signs that guide pronunciation." ${ }^{39}$ But even if they are to be taken as reading aids, they are so in a different way than the rudiment of paragraphing by the means of ekthesis. Similarly, apostrophes which mark elision and some geminate consonants, as in P.Egerton 2 + P.Köln VI 255, P.Oxy. II 210, P.Mich. 1317 + P.Mich. 3788 + P.Berol 13893, or P.Oxy. XIII 1599, look more like a writing convention than anything meant to help reading.

Indeed ekthesis - a letter protruded in the left margin at the beginning of a line, for instance in P. Oxy. LX 4009, PSI VII 757, or P.Oxy. L 3524 - can mark the beginning of a quotation or a new section in the narrative. Enlarged letters can mark the beginning of a sentence, as in P.Merton II 51 or P.Oxy. IV 654, but can also appear in the middle of paratactical constructions, where today we would have a modern comma, for instance in P.Egerton 2 + P.Köln VI 255. Paragraphi can be found in several apocryphal and apostolic fathers papyri, sometimes preceding a subtitle (P.Mich. II 2.129, P. Oxy. LXIX 4707, P.Bodmer 38), other times in the middle of a paragraph, seemingly marking for instance the shift in the narrative from the voice of a character to that of another (Bodl. Ms Gr. tb. f. 4 [P] + P.Vindob.G 39756), or even the shift from one explanation to another within the speech of the same character (P.Mich. II 2.129).

Diplae ( $>$ ) appear in several papyri, in various positions. They can be line-fillers as in P.Oxy. I 1 and P.Oxy. IV 655, or they can be in the margin of a column marking a quotation or a passage distinct in some other way, as in P.Bodmer 5. It can even occur at the end of the line but in the middle of a word, as in P.Oxy. V 840, in which case its purpose is less clear. Dots in various positions (low, mid, high, or in pairs as dicolon) and blank spaces of various sizes seem ubiquitous, but their function is not always clear, as they can appear in the middle of a word, for instance in Bodl. Ms Gr. tb. f. 4 [P] + P.Vindob.G 39756. Otherwise, such dots can precede the adversative $\alpha \lambda \lambda \alpha$ within the same sentence (P.Antinoopolis I 13), separate sentences, or coordinate parts of a sentence, being present where nowadays you would have a question mark or dicolon, for instance in P.Egerton 2 + P.Köln VI 255.

Overall, this material confirms the view according to which "abbreviations and lectional signs were employed infrequently, unsystematically, and at times in ways that render public reading more difficult." 40 These can be construed as lectional signs to the extent that they might have been meant to assist the act of reading. They can also be taken to be scribal markings if they reflect the scribes' effort or habit to make sense of the text they are transcribing. Of course, they can

39 Nässelqvist, Public Reading in Early Christianity, 25.

40 Nässelqvist, Public Reading in Early Christianity, 322. 
be seen both as reading aids and scribal markings, in as much as the activity of the scribe presupposes both acts. None of these markings is applied consistently in the same way punctuation (e.g. space) is used in English in any one manuscript - where enough of it has survived to make an informed judgement on the matter. Their main feature is that they are occasional in nature and therefore do not strictly mark sense units, a notion which would presuppose delimitations with both a beginning and an end. Indeed, it is rarely that they mark both the beginning and the end of a word, syntagm, sentence, or paragraph. These signs point to interruptions more than to "sense units" with a beginning and an end. In the most general sense, such para-textual signs mark a shift in the narrative, which, as seen, can be a new sentence, a new action, a shift from a character's voice to that of another, and so on. Especially blank spaces and dots (in all positions) can function in largely the same manner, interchangeably, separately or combined. But most of these signs can be used in the middle of the words as well, which further complicates the image.

\section{Concluding Remarks}

Perhaps expectedly, virtually all reading aids discussed by Charlesworth as part of the canonical gospel papyri - paragraphi, vacant end lines, ekthesis, enlarged first letter of verse or chapter, space, medial or highpoint, dicolon, diplae use as line filler or in other ways, and acute-like text division marker or miscellaneous stroke $\mathrm{e}^{41}$ - do appear in other apocrypha papyri and in those of the apostolic fathers. While I would agree that the paratextual features listed above are one way or another meant to assist the act of reading, the question remains as to what extent the available data allows us to distinguish with any degree of confidence that they are meant for public reading and not for private reading - or even loud as opposed to silent reading. ${ }^{42}$

41 Charlesworth, Early Christian Gospels, 121

42 For a recent re-assessment of the question of reading habits in antiquity, challenging the notion that only loud reading was the custom, see R. W. McCutcheon, "Silent Reading in Antiquity and the Future History of the Book,” Book History 18 (2015): 1-32, esp. 3-17, where evidence from Augustine (on Ambrose, in Confessions 6.3.3), Dionysius of Halicarnassus (De compositione verborum 25), Lucian (Adv. Ind. 2), Quintilian (Inst. Or. 1.1.34, 10.1.8-10, 11.3.2-4), Ovid (Heroides 21.3-4), Plutarch (on Caesar, in Brut. 5.2-3), Euripides (Hipp. 874-875), Aristophanes (Kn. 115-128), Cicero (Tusc. 5.116), Ptolemy (Judic. 5.2), Josephus (Vita 223), Ptolemy (Judic. 5.2), and the scholarly debates on these are presented and discussed. 
Recent studies offer new insights, admittedly, complicating things further. From the perspective of public reading in general - thus without the aggravations produced by introducing the canonical divide into the topic - Nässelqvist shows how our best papyri do not actually lend themselves to easy reading, and documents the need and presence, in early communities, of lectors, which were needed to make sense of the papyri and perform the content. They as well would have needed time to prepare the reading, as opposed to reading it on the spot. ${ }^{43}$ Also recently, Alan Mugridge, in an important book on Copying Early Christian Texts, argues that early Christian papyri were more likely copied by non-Christian scribes than by Christians, which would have been more or less professional copyists who would copy what we call Christian features like nomina sacra upon request, or from the exemplar along with everything else. ${ }^{44}$ This new proposal might not convince everyone, and it is not impossible that many will remain persuaded that it is more likely that they were copied by Christians. But what this proposal does is to move the discussion from the widely accepted, virtually unchallenged, presupposition that they were copied by Christians, to a question of likelihood. For all intents and purposes, "it is more likely" is quite different from "it is clear" when discussing whether or not early Christian papyri were written by Christians.

A very recent critique of the limitations of the public/private binary, in relation to previous claims that some Revelation papyri would have been "private", notes: "I fail to see why, in the third century C.E., a church cannot have employed a reused manuscript for purposes of communal worship - whatever form that communal worship may have taken," drawing attention to the weakness of a case that "rests on the assumption that a church could not have used a manuscript produced so "economically." "45 In a sense, the persistence of associating the quality of a papyrus with the importance of the text on it is surprising since already in 1979 C. H. Roberts was noting that "not all text written on improvised material need have been private. It may have been a paper shortage or just poverty that led one church to economize by sticking together sheets of papyrus already written on one side, fold them, and so form a makeshift codex out of the unwritten side."46

Indeed, not only do we lack the means of establishing whether a papyrus was meant for public or private reading in the absence of clear testimonies in this

43 Nässelqvist, Public Reading in Early Christianity, 322.

44 Alan Mugridge, Copying Early Christian Texts: A Study in Scribal Practice, WUNT 362 (Tübingen: Mohr Siebeck, 2016), 144-54.

45 Malik, “The Greek Text of Revelation in Late Antique Egypt," 405, n. 21.

46 Colin H. Roberts, Manuscript, Society and Belief in Early Christian Egypt: The Schweich Lectures 1977 (Oxford: Oxford University Press, 1979), 9-10, also quoted in this regard in Malik, "The Greek Text of Revelation in Late Antique Egypt,” 405, n. 21. 
sense (e.g. an explicit colophon), but when we draw too clear-cut a distinction between public and private papyri, we run the risk of oversimplifying the reading culture of early and late-antique Christianity. Just how uniform an early Christianity should we envisage? Can we not imagine a poor church community using a smaller and poorly written canonical gospel papyrus, or a well-off individual with many excellently looking New Testament codices? Or should we imagine there were no poor churches at all in late-antique Christianity? One might wonder what we are left with if we drop this apparently very attractive yet deceitful assumption. We are left with no small thing: reading aids in manuscripts become once again a very interesting and complex issue which still provides a window into the material culture of early and late-antique Christians, and at the same time into the reception history of the text so marked, which should indeed invite further but perhaps less essentialized - study.

\section{Bibliography}

Batovici, Dan. “The Apostolic Fathers in Codex Sinaiticus and Alexandrinus.” Biblica 97 (2016): 581-605.

Bazzana, Giovanni. “'Write in a Book What You See and Send It to the Seven Assemblies:' Ancient Reading Practices and the Earliest Papyri of Revelation." In Book of Seven Seals: The Peculiarity of Revelation, its Manuscripts, Attestation, and Transmission, edited by Thomas J. Kraus and Michael Sommer, 11-31. WUNT 363. Tübingen: Mohr Siebeck, 2016.

Blumell, Lincoln H. Lettered Christians: Christians, Letters, and Late Antique Oxyrhynchus. NTTSD 39. Leiden/Boston: Brill, 2012.

Blumell, Lincoln H. and Thomas A. Wayment, Christian Oxyrhynchus: Texts, Documents, and Sources. Baylor: Baylor University Press, 2018.

Chapa, Juan. "Su demoni e angeli: Il Salmo 90 nel suo contesto." In I papiri letterari Cristiani: atti del Convegno internazionale di studi in memoria di Mario Naldini. Firenze, 10-11 giugno 2010, edited by Guido Bastianini and Angelo Casanova, 59-90. Studi e Testi di Papirologia N.S. 13. Firenze: Instituto Papirologico “G. Vitelli," 2011.

Charlesworth, Scott D. Early Christian Gospels: Their Production and Transmission. Papyrologica Florentina 47. Firenze: Edizioni Gonnelli, 2016.

Charlesworth, Scott D. "Public and Private: Second- and Third-Century Gospel Manuscripts." In Jewish and Christian Scripture as Artifact and Canon, edited by Craig A. Evans and H. Daniel Zacharias, 148-75. LSTS 70. London: Bloomsbury, 2009.

Charlesworth, Scott D. "Consensus Standardization in the Systematic Approach to Nomina Sacra in Second- and Third-Century Gospel Manuscripts." Aegyptus 86 (2006): 37-68.

Gacek, Adam. Arabic Manuscripts: A Vademecum for Readers. HOSNME 98. Leiden: Brill, 2009. Haines-Eitzen, Kim. "Social History of Early Christian Scribes." In The Text of the New Testament in Contemporary Research: Essays on the Status Quaestionis, edited by Bart D. Ehrman and Michael W. Holmes, 479-95. NTTSD 42. Leiden: Brill, 2013. 
Haines-Eitzen, Kim. Guardians of Letters: Literacy, Power and the Transmitters of Early Christian Literature. Oxford: Oxford University Press, 2000.

Hurtado, Larry W. "The Greek Fragments of the Gospel of Thomas as Artefacts: Papyrological Observations on Papyrus Oxyrhynchus 1, Papyrus Oxyrhynchus 654 and Papyrus Oxyrhynchus 655." In Das Thomasevangelium: Entstehung - Rezeption - Theologie, edited by J. Frey, E.E. Popkes and Jens Schröter, 19-32. BZNW 157. Berlin: de Gruyter, 2008.

Hurtado, Larry W. The Earliest Christian Artifacts: Manuscripts and Christian Origins. Grand Rapids, MI: Eerdmans, 2006.

Layton, Bentley. The Gnostic Scriptures: A New Translation with Annotations and Introductions. New York: Doubleday, 1987.

Luijendijk, AnneMarie. "Reading the Gospel of Thomas in the Third Century: Three Oxyrhynchus Papyri and Origen's Homilies." In Reading New Testament Papyri in Context/Lire les papyrus du Nouveau Testament dans leur contexte, edited by C. Clivaz and J. Zumstein, 241-67. BETL 242. Leuven: Peeters, 2011.

Luijendijk, AnneMarie. Greetings in the Lord: Early Christians and the Oxyrhynchus Papyri. HTS 60; Cambridge, MS: Harvard University Press, 2008.

Malik, Peter. "The Greek Text of Revelation in Late Antique Egypt: Materials, Texts, and Social History." Zeitschrift für antikes Christentum 22.3 (2018): 400-21.

McCutcheon, R.W. "Silent Reading in Antiquity and the Future History of the Book." Book History 18 (2015): 1-32.

McNamee, Kathleen. "Sigla in Late Greek Literary Papyri." In Signes dans les textes, textes sur les signes: Érudition, lecture et écriture dans le monde gréco-romain, edited by Gabriel Nocchi Macedo and Maria Chiara Scappaticcio, 127-41. Papyrologica Leodiensia 6. Liège: Presses Universitaires de Liège, 2017.

Mugridge, Alan. Copying Early Christian Texts: A Study in Scribal Practice. WUNT 362. Tübingen: Mohr Siebeck, 2016.

Nässelqvist, Dan. Public Reading in Early Christianity: Lectors, Manuscripts, and Sound in the Oral Delivery of John 1-4. NovTSup 163. Leiden: Brill, 2016.

Nocchi Macedo, Gabriel and Maria Chiara Scappaticcio (eds.). Signes dans les textes, textes sur les signes: Érudition, lecture et écriture dans le monde gréco-romain. Papyrologica Leodiensia 6. Liège: Presses Universitaires de Liège, 2017.

Reed, Stephen. "Physical Features of Excerpted Torah Texts." In Jewish and Christian Scripture as Artifact and Canon, edited by Craig A. Evans and H. Daniel Zacharias, 82-104. LSTS 60. London: Bloomsbury, 2009.

Roberts, Colin H. Manuscript, Society and Belief in Early Christian Egypt: The Schweich Lectures 1977. Oxford: Oxford University Press, 1979.

Tov, Emanuel. Scribal Practices and Approaches Reflected in the Texts Found in the Judean Desert. STDJ 54. Leiden: Brill, 2004.

Tuckett, Christopher. "What is Early Christian Apocrypha?" In The Oxford Handbook of Early Christian Apocrypha, edited by Andrew Gregory and Christopher Tuckett, 3-12. Oxford: Oxford University Press, 2015.

Turner, E.G. Greek Manuscripts of the Ancient World. Second edition revised and enlarged, edited by P.J. Parsons. London: Institute of Classical Studies, 1987.

Wayment, Thomas A. The Text of the New Testament Apocrypha (100-400). New York: Bloomsbury, 2013.

Zelyck, Lorne R. John among the Other Gospels. WUNT 2.347. Tübingen: Mohr Siebeck, 2013. 
